\title{
Differential regulation of proliferation, cell cycle control and gene expression in cultured human aortic and pulmonary artery endothelial cells by resveratrol
}

\author{
TZE-CHEN HSIEH, XIAOHUA LU, JUNQIAO GUO and JOSEPH M. WU \\ Department of Biochemistry and Molecular Biology, New York Medical College, Valhalla, NY 10595, USA
}

Received July 13, 2010; Accepted August 9, 2010

DOI: 10.3892/ijmm_00000521

\begin{abstract}
Resveratrol is a grape polyphenol with cardioprotective attributes, supported in part by its demonstrated anti-mitogenic, apoptosis-inducing and gene modulatory activities in various cell types known to play an integral role in atherogenesis. To test whether resveratrol exerts similar effects on systemic and pulmonary vasculature, cells derived from different anatomical sites, cultured human aortic and pulmonary artery endothelial cells, respectively denoted HAECs and HPAECs, were exposed to resveratrol for assessment of effects on proliferation, cell cycle distribution, induction of apoptosis, and specific gene expression. Resveratrol inhibited cell proliferation in a time- and dosedependent manner in HAECs and HPAECs, accompanied by disruption of cell cycle control and progression as assayed by flow cytometry. Analysis of gene changes in resveratroltreated endothelial cells by RT-PCR showed suppression of nitric oxide synthase (eNOS) and preproendothelin-1 (ppET-1) expression in both cell types. To discover group gene alterations resulting from exposure to resveratrol, changes in mRNA levels were determined by human signal transduction pathway finder cDNA array analysis. The results showed that resveratrol up-regulated levels of cyclin-dependent kinase inhibitor p57, egr-1, forkhead box A2 and c-jun in HAECs, and elevated expression of cathepsin D, ICAM-1, c-jun and patched 1 in HPAECs. In addition, treatment by resveratrol also resulted in attenuated expression of bcl-xl, fibronectin-1, HIP, mdm2, PIG3 and WSB1/SWIP-1 in HAECs, and CDX1, engrailed homolog 1, FASN, fibronectin-1, forkhead box A2, Hoxa-1, hsp27, PIG3, ELAM-1/E-selectin and WSB1/SWIP-1 in HPAECs. These results suggest that resveratrol acts by distinct and overlapping signaling pathways and mechanisms in HAECs and HPAECs, further supporting the notion that the cardioactive activities and effects of this
\end{abstract}

Correspondence to: Dr Joseph M. Wu, Department of Biochemistry and Molecular Biology, Room 147, Basic Sciences Building, New York Medical College, Valhalla, NY 10595, USA

E-mail: joseph_wu@nymc.edu

Key words: resveratrol, human aortic endothelial cells, human pulmonary aortic endothelial cells, cell proliferation, cell cycle control grape polyphenol are contingent upon or influenced by the vascular bed of origin.

\section{Introduction}

Atherosclerosis (AS) and pulmonary arterial hypertension (PAH) have a pronounced and significant association with cardiovascular diseases (CVD), and both are considered major causes of morbidity and mortality in developed countries (1-4). CVD currently claims the lives of 500,000 men and women annually in the USA. However, in spite of concerted efforts in education, research and prevention programs actively introduced over the past few decades to curtail CVD-related death rates, evidence of improved statistics is simply lacking. The previously identified major risk factors for CVD are cigarette smoking, hypertension, and hypercholesterolemia. Interestingly, these may not be sufficiently robust or reliable as predictors of new cases of CVD $(5,6)$ suggesting that protective factors exist that act to counteract and mitigate the deleterious consequences of the major CVD risk factors. In support of this possibility, recent data have shown that certain diet and dietderived chemicals may play a role in reducing and ameliorating the damage induced by exposure to risk factors of CVD (7-10). Therefore, the discovery and identification of protective dietary factors and elucidation of the mechanisms by which they confer cardioprotection may be envisaged to shed light on new CVD management strategies.

Resveratrol is a polyphenol present in abundance in several foods and red wine, which has been intensively studied in recent years stemming from the 'French paradox', the population-based epidemiological phenomenon showing an inverse correlation between the risk for CVD and low-tomoderate consumption of red wine with meals, possibly attributing to phytochemicals contained in red wine, e.g., resveratrol (11-14). The cardioprotective role of resveratrol has been supported by studies from this and other laboratories showing that this grape polyphenol (i) suppresses LDL oxidation $(15,16)$, (ii) reduces SMC proliferation (17-19), (iii) inhibits platelet aggregation (20-22), (iv) attenuates intimal thickening in rabbits fed a hypercholesterolemic diet and subjected to endothelium denudation $(23,24)$, and (v) induces nitric oxide synthase (NOS) in cultured bovine pulmonary artery endothelial cells (BPAEC) (25-27). To date, only scant data and mechanisms currently exist regarding the effects of this grape polyphenol in human endothelial cells, 
notwithstanding that these cells are integrally involved in controlling the homeostasis of the vasculature and the initiation of atherosclerosis (12). Because vascular diseases show an anatomically defined focal distribution, it is of interest to determine whether the spatiotemporal response, regulation, and function of endothelial cells to CVD, risk and protective factors, are contingent upon the source of the vasculature from which endothelial cells originate (28-31). Similarly, it has not been established whether the cardioactive effects of resveratrol might have subtle or marked dependence on the anatomical origin of endothelial cells. In the present study, we studied the responses of HAECs and HPAECs to resveratrol, in the context of suppression of cell growth, cell cycle phase distribution, induction of apoptosis, and changes in gene expression.

\section{Materials and methods}

Materials. HAECs and HPAECs were purchased from Lonza Walkersville Inc. (Walkersville, MD, USA), and were cultured and propagated using Clonetics ${ }^{\circledR}$ EGM $^{\circledR}-2$ BulletKit ${ }^{\circledR}$ containing endothelial cell basal medium-2 and growth supplements, as recommended by the manufacturer (Lonza Walkersville Inc.). Cells were maintained in a $\mathrm{CO}_{2}$ incubator and media were changed every 3-4 days. Resveratrol was dissolved in dimethyl sulfoxide (DMSO) as a $12.5 \mathrm{mM}$ stock and kept in aliquots at $-20^{\circ} \mathrm{C}$. All other chemicals and solvents used were of analytical grade.

Cell culture and proliferation assay. HAECs and HPAECs maintained in culture media as described were grown to $>70 \%$ confluence, and then split 1:4 into T-25 flasks containing fresh media. Following an overnight incubation, cells were exposed to increasing concentrations of resveratrol as specified in the text. Cell numbers were determined at the indicated times by trypan blue exclusion, as previously described (32-34).

Cell cycle analysis. HAECs and HPAECs were treated with resveratrol $(0,1,10$, and $100 \mu \mathrm{M})$ for 24 or $48 \mathrm{~h}$, and cell cycle phase distribution was assayed by flow cytometry as described $(33,35,36)$. The cellular DNA content was obtained and the percentage of cells in the respective phases $\left(G_{1}, S\right.$ and $\left.\mathrm{G}_{2} / \mathrm{M}\right)$ of the cell cycle was quantified.

RNA extraction and reverse transcription-polymerase chain reaction $(R T-P C R)$. Total cellular RNA was isolated from control and resveratrol treated cells, using Trizol reagent (Invitrogen, Carlsbad, CA) according to protocols provided by the manufacturer. The first strand cDNA was synthesized from $2 \mu \mathrm{g}$ of total RNA, using Superscript ${ }^{\mathrm{TM}}$ RNase H-reverse transcriptase (Invitrogen, Carlsbad, CA). The PCR reaction was performed using $1 \mu \mathrm{l} \mathrm{cDNA}$ synthesis reaction mixture according to the following conditions, eNOS, $94^{\circ} \mathrm{C} 1 \mathrm{~min}, 60^{\circ} \mathrm{C}$ $1 \mathrm{~min}, 72^{\circ} \mathrm{C} 1 \mathrm{~min}, 32$ cycles; ppET- $1,94^{\circ} \mathrm{C} 1 \mathrm{~min}, 60^{\circ} \mathrm{C} 1 \mathrm{~min}$, $72^{\circ} \mathrm{C} 1 \mathrm{~min}, 34$ cycles; GAPDH, $94^{\circ} \mathrm{C} 1 \mathrm{~min}, 60^{\circ} \mathrm{C} 1 \mathrm{~min}$, $72^{\circ} \mathrm{C} 1 \mathrm{~min}, 26$ cycles, and using the following primer sets: eNOS, forward and backward primer sets, 5'-CCC TTC AGT GGC TGG TAC AT-3'/5'-GAA AAC AGG AGT GAG GCT GC-3', expected size 327 bp; ppET-1, forward and backward primer sets, 5'-TCC AAG AGA GCC TTG GAG AA-3'/
5'-ATG GAA GCC AGT GAA GAT GG-3', expected size 565 bp; GAPDH, forward and backward primer sets, 5'-CCA CCC ATG GCA AAT TCC ATG GCA-3'/5'-TCT AGA CGG CAG GTC AGG TCC ACC-3', expected size 598 bp. The PCR products were resolved on $1.2 \%$ agarose gels. The relative intensity of fragments with the expected sizes was determined using the Innotech imaging system $(37,38)$.

cDNA array analysis. Total RNA was isolated from day 2 control and $100 \mu \mathrm{M}$ resveratrol-treated cells. RNA $(4 \mu \mathrm{g})$ was used as the template for biotinylated cDNA synthesis. Hybridization of biotinylated cDNA to immobilized genespecific cDNAs and detection of hybridization signals by chemiluminescence were according to the manufacturer's protocol (Superarray, Bethesda, MD), as described (34,38,39). Briefly, membrane was prehybridized in solution containing $100 \mathrm{mg} / \mathrm{ml}$ heat-denatured, sheared salmon sperm DNA for $2 \mathrm{~h}$ at $60^{\circ} \mathrm{C}$ followed by overnight incubation with the denatured cDNA probe, with shaking at $10 \mathrm{rpm} / \mathrm{min}, 60^{\circ} \mathrm{C}$. Membrane was washed, blocked for $40 \mathrm{~min}$ with solution $\mathrm{Q}$ provided by the manufacturer, and incubated with AP-streptavidin for $10 \mathrm{~min}$ at room temperature. Next, the membrane was washed and rinsed with CDP-Star chemiluminescent substrate followed by exposure to X-ray film. The data were analyzed using GEArray Analyzed software.

\section{Results}

Effects of resveratrol on growth and cell cycle distribution in cultured HAECs. To obtain information on overall cell response to resveratrol by HAECs, the growth modulatory effects of resveratrol were studied. Cells were incubated with 0 or $100 \mu \mathrm{M}$ resveratrol for 24 or $48 \mathrm{~h}$, or with increasing concentrations of resveratrol $(0,1,10$ or $100 \mu \mathrm{M})$ for $48 \mathrm{~h}$. Cell number was determined by trypan blue exclusion assay. Exposure to resveratrol resulted in time- and dose-dependent inhibition of growth, compared with controls. Growth suppression was $\sim 48 \%$ at $24 \mathrm{~h}$ exposure to $100 \mu \mathrm{M}$ resveratrol (Fig. 1A). By $48 \mathrm{~h}$ an $\sim 58$ and $\sim 73 \%$ diminution of cell growth was observed in cells treated with 10 and $100 \mu \mathrm{M}$ resveratrol, respectively (Fig. 1B). To test whether resveratrol-induced growth suppression in HAECs might involve alterations in cell cycle control, flow cytometry studies were performed. Cells treated with $100 \mu \mathrm{M}$ resveratrol for 24 or $48 \mathrm{~h}$ both showed an increase in $\mathrm{G}_{1}$ phase cell population ( $\sim 75 \%$ in control vs. $\sim 89 \%$ in treated cells) accompanied by a concomitant reduction in the S phase cell population $(\sim 12 \%$ in control vs. $\sim 2.5 \%$ in treated cells), and a slight increase in induction of apoptosis (from $\sim 2.3$ in control to $3.6 \%$ in treated cells) (Fig. 1C). In cells treated with $0,1,10$ or $100 \mu \mathrm{M}$ resveratrol for $48 \mathrm{~h}$ there was a similar increase in $\mathrm{G}_{1}$ phase cell population accompanied by a concomitant reduction in the $S$ phase cell population by 1 and $100 \mu \mathrm{M}$ resveratrol treatment. However, $10 \mu \mathrm{M}$ resveratrol treatment resulted in a reduction in $G_{1}$ phase accompanied by an increase in S phase (Fig. 1D). These results suggest that resveratrol controls mitogenesis in HAECs.

Effects of resveratrol on growth and cell cycle distribution in cultured HPAECs. The response of HPAECs to resveratrol was also investigated with respect to growth suppression and 
A

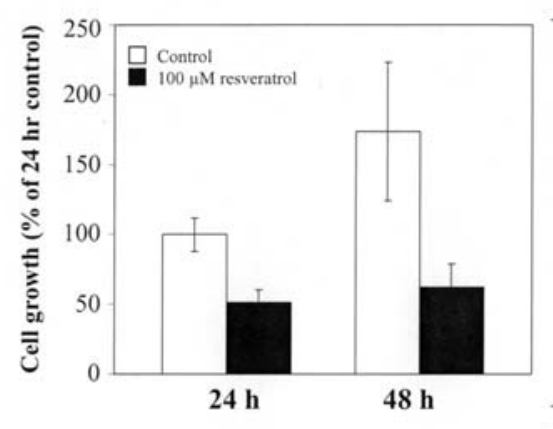

C

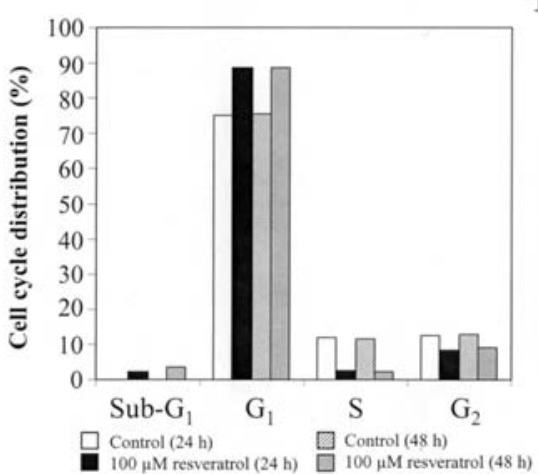

B

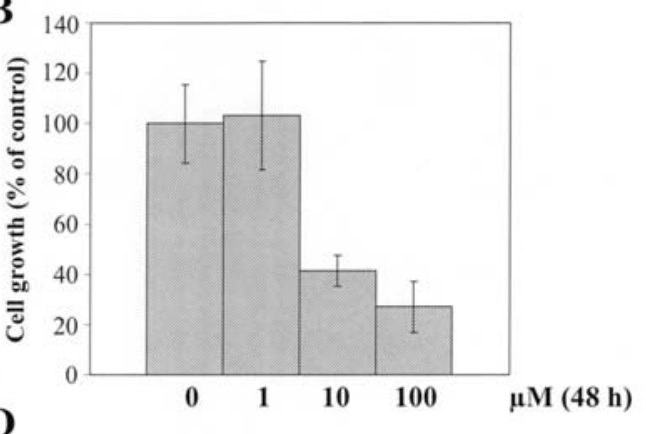

D

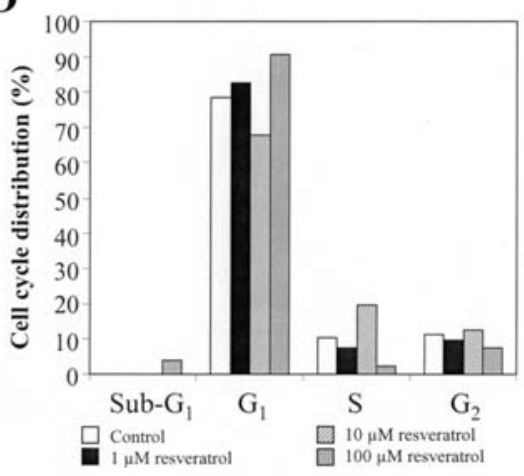

Figure 1. Effects of resveratrol on growth and cell cycle distribution in cultured HAECs. (A) Growth of HAECs exposed to 0 or $100 \mu \mathrm{M}$ of resveratrol for 24 or $48 \mathrm{~h}$, respectively. Results represent the mean of triplicate experiments \pm SD. (B) Growth of HAECs treated for $48 \mathrm{~h}$ with increasing resveratrol $(1,10,100 \mu \mathrm{M})$. Results show the mean of triplicate experiments \pm SD. (C) Effects of resveratrol on the changes of cell cycle phase distribution in HAECs. Cells were treated with 0 or $100 \mu \mathrm{M}$ of resveratrol for 24 or $48 \mathrm{~h}$, and analyzed by flow cytometry. The percentage of cells in $\mathrm{G}_{1}, \mathrm{~S}$, and $\mathrm{G}_{2}$ phases were determined and are presented as bar graphs. (D) Changes of cell cycle phase distribution in HAECs treated with $0,1,10$ or $100 \mu \mathrm{M}$ of resveratrol for $48 \mathrm{~h}$. The effects of resveratrol on cell cycle distribution, respectively, as the percentage of cells in $\mathrm{G}_{1}, \mathrm{~S}$, and $\mathrm{G}_{2}$ phases are presented as bar graphs.

A

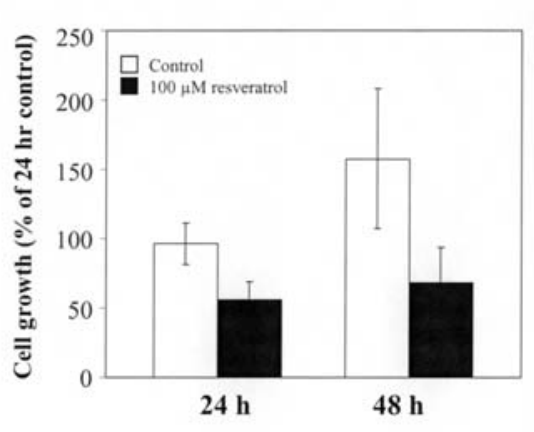

C

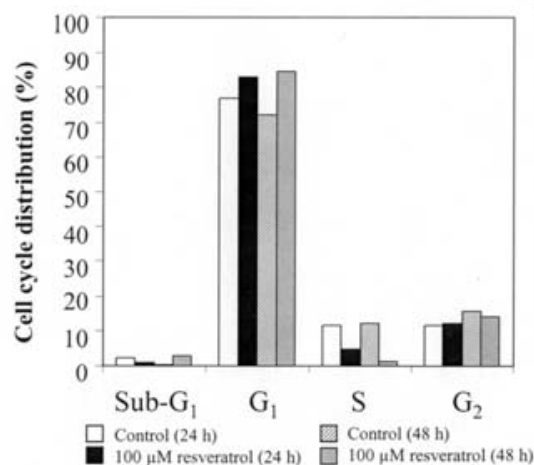

B

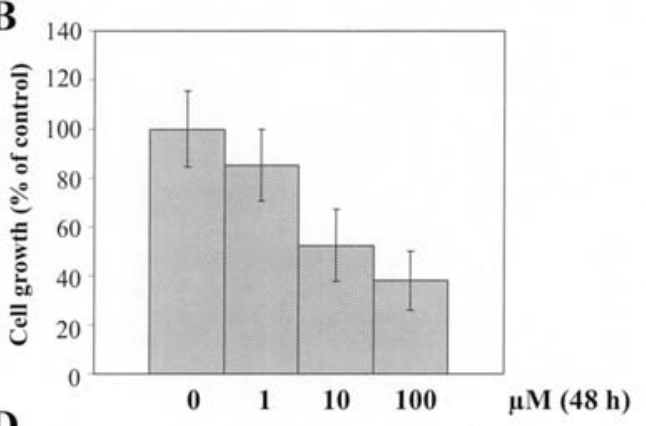

D

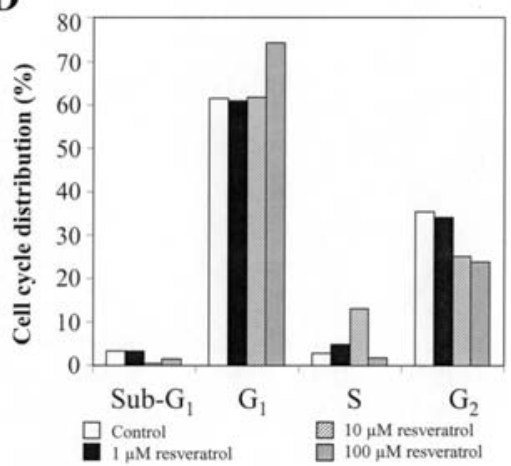

Figure 2. Effects of resveratrol on growth and cell cycle distribution in cultured HPAECs. (A) HPAECs were exposed to 0 or $100 \mu \mathrm{M}$ of resveratrol for 24 or $48 \mathrm{~h}$, and growth in control and treated cells are shown as the mean of triplicate experiments \pm SD. (B) Exposure of HPAECs for $48 \mathrm{~h}$ with increasing dose $(0$, $1,10,100 \mu \mathrm{M}$ ) of resveratrol, and results on growth are presented as the mean of triplicate experiments $\pm \mathrm{SD}$. (C) Effects of resveratrol on the changes of cell cycle phase distribution in HPAECs. Cells treated with 0 or $100 \mu \mathrm{M}$ of resveratrol for 24 or $48 \mathrm{~h}$ were analyzed by flow cytometry, and the percentage of cells in $\mathrm{G}_{1}, \mathrm{~S}$, and $\mathrm{G}_{2}$ phases are shown as bar graphs. (D) Induction of cell cycle phase distribution changes in HPAECs treated with $0,1,10$ or $100 \mu \mathrm{M}$ of resveratrol for $48 \mathrm{~h}$. The induced changes in cell cycle distribution as relative percentage of cells in $\mathrm{G}_{1}, \mathrm{~S}$, and $\mathrm{G}_{2}$ phases, resulting from treatment by resveratrol are shown as bar graphs. 
Table I. Identity of specific genes regulated by resveratrol in HAEC.

\begin{tabular}{|c|c|c|c|c|}
\hline Genebank & Gene name & Description & Pathway & Regulation \\
\hline U22398 & p57Kip2 & $\begin{array}{l}\text { Cyclin-dependent kinase } \\
\text { inhibitor } 1 \mathrm{C}(\mathrm{p} 57, \text { Kip } 2)\end{array}$ & $\mathrm{TGFb}$ & $\uparrow$ \\
\hline X52541 & egr-1 & Early growth response 1 & $\begin{array}{l}\text { Mitogenic, creb, } \\
\text { phospholipase C }\end{array}$ & $\uparrow$ \\
\hline AB028021 & Forkhead box A2 & Hepatocyte nuclear factor $3, \beta$ & Hedgehog & $\uparrow$ \\
\hline J04111 & c-jun & $\begin{array}{l}\text { v-jun avian sarcoma virus } 17 \\
\text { oncogene homolog }\end{array}$ & $\begin{array}{l}\text { Mitogenic, wnt, survival, } \\
\text { calcium and protein } \\
\text { kinase } \mathrm{C} \text {, phospholipase } \mathrm{C}\end{array}$ & $\uparrow$ \\
\hline $\mathrm{Z} 23115$ & bcl-xl & $\begin{array}{l}\text { Homo sapiens BCL2-like } 1 \\
\text { (BCL2L1) }\end{array}$ & Survival & $\downarrow$ \\
\hline X02761 & Fibronectin-1 & Fibronectin 1 & Survival & $\downarrow$ \\
\hline AY009317 & HIP & Hedgehog-interacting protein & Hedgehog & $\downarrow$ \\
\hline Z12020 & $\mathrm{mdm} 2$ & $\begin{array}{l}\text { Mouse double minute } 2 \text {, human } \\
\text { homolog of p53-binding protein }\end{array}$ & p53 & $\downarrow$ \\
\hline NM_004881 & PIG3 & Quinone oxidoreductase homolog & p53 & $\downarrow$ \\
\hline NM_015626 & WSB1/SWIP-1 & $\begin{array}{l}\text { SOCS box-containing WD protein } \\
\text { SWiP-1 (SWIP1) }\end{array}$ & Hedgehog & $\downarrow$ \\
\hline
\end{tabular}

Up-regulation; ‘down-regulation.

cell cycle phase distribution. Cells were treated with different concentrations of resveratrol for variable time periods and growth was determined. Exposure to resveratrol resulted in time- and dose-dependent inhibition of proliferation, relative to controls, yielding $\sim 42 \%$ growth suppression in $24 \mathrm{~h}, 100 \mu \mathrm{M}$ resveratrol-treated cells (Fig. 2A). In 48-h exposed cell cultures, an $\sim 15, \sim 47$ and $\sim 62 \%$ diminution of cell growth was observed in 1, 10 and $100 \mu \mathrm{M}$ resveratrol treated samples (Fig. 2B). To further validate the anti-proliferative activity of resveratrol on HPAECs, the changes in cell cycle distribution were assayed by flow cytometry. Although there was no observed time-dependent difference on cell cycle distribution following treatment with $100 \mu \mathrm{M}$ resveratrol, exposure to the grape polyphenol nevertheless increased $\mathrm{G}_{1}$ phase cell population ( $\sim 74 \%$ in control vs. $\sim 83.5 \%$ in treated cells), in concomitance with a comparable reduction in the $\mathrm{S}$ phase cell population $(\sim 12 \%$ in control vs. $\sim 3.5 \%$ in treated cells) (Fig. 2C). Moreover, whereas cells treated with $10 \mu \mathrm{M}$ resveratrol for $48 \mathrm{~h}$ showed restriction in the $\mathrm{S}$ phase, treatment with $100 \mu \mathrm{M}$ resveratrol induced a $\mathrm{G}_{1}$ phase arrest (Fig. 2D), suggesting that resveratrol also plays a regulatory role in the control of mitogenesis in HPAECs.

Effects of resveratrol on eNOS and ppET-1 gene expression in cultured HAECs and HPAECs. The expression of endothelial cell specific genes, respectively, eNOS and ppET-1 (40) was assayed to determine whether treatment by resveratrol elicited a differential gene change in HAECs and HPAECs. To this end, levels of eNOS and ppET-1 mRNA in control and resveratrol-treated HAECs and HPAECs were analyzed by RT-PCR. Time-dependent decreases in eNOS and ppET-1 expression were observed in $100 \mu \mathrm{M}$ resveratrol-treated HAECs. By contrast, in HPAECs, resveratrol only induced time-dependent inhibition in eNOS expression while the suppression of ppET-1 by resveratrol was only seen in 24-h
A
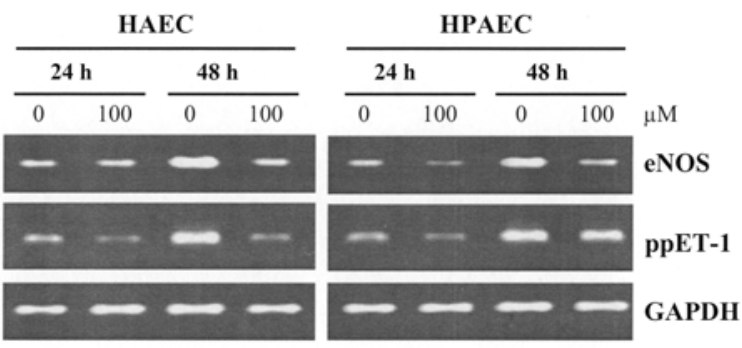

B
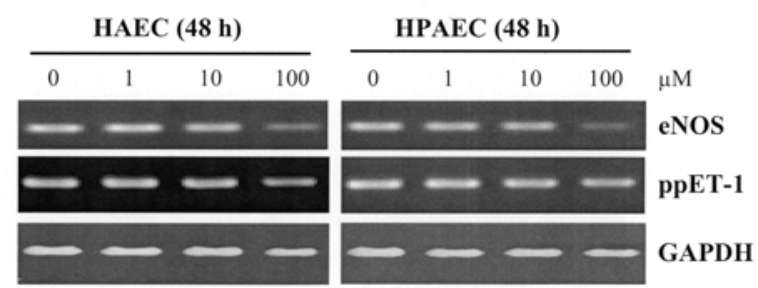

Figure 3. Control of eNOS and ppET-1 gene expression by resveratrol in HAECs and HPAECs. (A) Cells were treated with 0 or $100 \mu \mathrm{M}$ of resveratrol for 24 or $48 \mathrm{~h}$, harvested and analyzed for changes in eNOS and ppET-1 expression, by RT-PCR as detailed in Materials and methods. (B) Effects of increasing concentrations of resveratrol $(0,1,10$ and $100 \mu \mathrm{M})$ on eNOS and ppET-1 expression. Control and $48 \mathrm{~h}$ resveratrol-exposed HAECs and HPAECs were harvested and used for determination of eNOS and ppET-1 mRNA level changes by RT-PCR. In these experiments, the expression of glyceraldehyde-3-phosphate dehydrogenase (GAPDH) was used as an internal control to verify equivalent RNA loading.

treated cells (Fig. 3A). A dose-dependent study revealed that the reduction of eNOS was only seen in both HAECs and HPAECs treated with $100 \mu \mathrm{M}$ resveratrol for $48 \mathrm{~h}$ while resveratrol reduced ppET-1 expression only in HAECs but not in HPAECs (Fig. 3B). These results suggest that resveratrol differentially controls eNOS and ppET-1 expression, in a cell type-dependent manner. 
Table II. Identity of specific genes regulated by resveratrol in HPAEC.

\begin{tabular}{|c|c|c|c|c|}
\hline Genebank & Gene name & Description & Pathway & Regulation \\
\hline M11233 & Cathepsin D & $\begin{array}{l}\text { Cathepsin D (lysosomal } \\
\text { aspartyl prostease) }\end{array}$ & $\begin{array}{l}\text { Estrogen, } \\
\text { retinoic acid }\end{array}$ & $\uparrow$ \\
\hline NM_000201 & ICAM-1 & $\begin{array}{l}\text { Intercellular adhesion molecule } 1 \\
\text { (CD54), human rhinovirus receptor }\end{array}$ & NF-кB, phospholipase c & $\uparrow$ \\
\hline J04111 & c-jun & $\begin{array}{l}\text { v-jun avian sarcoma virus } 17 \\
\text { oncogene homolog }\end{array}$ & $\begin{array}{l}\text { Mitogenic, wnt, survival, } \\
\text { calcium and protein } \\
\text { kinase } \mathrm{C} \text {, phospholipase C }\end{array}$ & $\uparrow$ \\
\hline U43148 & Patched 1 & Patched (Drosophila) homolog 1 & Hedgehog & $\uparrow$ \\
\hline NM_001804 & CDX1 & $\begin{array}{l}\text { Homo sapiens caudal type homeo } \\
\text { box transcription factor } 1 \text { (CDX1) }\end{array}$ & Retinoic acid & $\downarrow$ \\
\hline NM_001426 & Engrailed homolog 1 & Engrailed homolog 1 & Hedgehog; Retinoic acid & $\downarrow$ \\
\hline U26644 & FASN & Fatty acid synthase & Insulin & $\downarrow$ \\
\hline X02761 & Fibronectin-1 & Fibronectin 1 & Survival & $\downarrow$ \\
\hline AB028021 & Forkhead box A2 & Hepatocyte nuclear factor $3, \beta$ & Hedgehog & $\downarrow$ \\
\hline NM_005522 & Hoxa-1 & $\begin{array}{l}\text { Homo sapiens homeo box A1 } \\
\text { (HOXA1) }\end{array}$ & Retinoic acid & $\downarrow$ \\
\hline Z23090 & Hsp27 & Heat shock $27 \mathrm{kD}$ protein & Stress & $\downarrow$ \\
\hline NM_004881 & PIG3 & Quinone oxidoreductase homolog & p53 & $\downarrow$ \\
\hline M30640 & ELAM-1/E-selectin & $\begin{array}{l}\text { Human endothelial leukocyte } \\
\text { adhesion molecule } 1 \text { (ELAM1) mRNA }\end{array}$ & LDL & $\downarrow$ \\
\hline NM_015626 & WSB1/SWIP-1 & $\begin{array}{l}\text { SOCS box-containing WD protein } \\
\text { SWiP-1 (SWIP1) }\end{array}$ & Hedgehog & $\downarrow$ \\
\hline
\end{tabular}

Up-regulation; ‘down-regulation.

Effects of resveratrol on expression of cell signal transduction genes in HAECs and HPAECs. To define group gene changes in HAECs and HPAECs that respond to exposure to resveratrol treatment, human Signal Transduction PathwayFinder cDNA GEArray was used since it was designed to explore aggregate gene expression changes associated with 18 signal transduction pathways. To test the feasibility and validity of this approach, cells were treated with $100 \mu \mathrm{M}$ resveratrol for 2 days and used in the analysis. In HAECs, p57Kip2, egr-1, forkhead box A2 and c-jun showed up-regulation with treatment by $100 \mu \mathrm{M}$ of resveratrol. In contrast, 6 genes (bcl-xl, fibronectin-1, HIP, mdm2, PIG3 and WSB1/SWIP-1) having an integral role on different facets of control of cell signaling were down-regulated by resveratrol (Table I). In HPAECs, resveratrol resulted in increased expression of cathepsin D, ICAM-1, c-jun and patched 1 gene expression, while concurrently suppressing the levels of 10 genes, respectively, CDX1, engrailed homolog 1, FASN, fibronectin-1, forkhead box A2, Hoxa-1, hsp27, PIG3, ELAM-1/E-selectin and WSB1/SWIP-1 (Table II). These results provide further evidence that there is a differential control of signal transduction by resveratrol and this control is cell type-dependent.

\section{Discussion}

Resveratrol shows cardioprotective attributes based on in vitro and in vivo data obtained using tissue culture cells and experiments involving animals $(12,22,41,42)$. However, relatively fewer studies have addressed the activities of resveratrol on vascular components, including endothelial cells derived from humans, particularly those derived from different anatomical sites. In this study, we investigated whether resveratrol exerts similar effects in two normal human endothelial cells, HAECs and HPAECs, in terms of their growth and gene regulatory activities. Results of this study provide several hitherto unreported observations lending further support for the cardioprotective potential of this grape polyphenol: (i) resveratrol significantly and differentially inhibits the proliferation of both HAECs and HPAECs (Figs. 1 and 2), (ii) resveratrol alters cell cycle distribution in HAECs and HPAECs (Figs. 1 and 2), (iii) resveratrol inhibits the expression of eNOS and ppET-1 in HAECs but only exerted transient inhibitory effect on ppET-1 expression in HPAECs (24 but not $48 \mathrm{~h}$ of exposure to resveratrol) (Fig. 3A), (iv) resveratrol induces distinct and overlapping changes in signal transduction pathways in HAECs and HPAECs. Taken together, these results are consistent and support the interpretation that resveratrol exerts cardioactive affects on normal endotheial cells, possibly targeting differential mechanistic control on cell signaling pathways that impinge on the control of cell growth, thus befitting the rubric of efficacy as a cardioprotective agent.

The vascular smooth muscle and endothelial cells both play a significant role in the maintenance of vascular tone in the adult blood vessel $(12,22,40)$. Under certain pathological conditions aberrant cell proliferation in smooth muscle or artery endothelial cells may lead to disorder of vascular remodeling as an antecedent to the pathological sequelae of CVD. Previously, we have shown that resveratrol inhibited human aortic smooth muscle cell proliferation (40). The results of this study show that resveratrol also suppressed proliferation of HAECs and 
HPAECs in concert with disruption of cell cycle progression. Accordingly, restriction of HAECs growth by resveratrol could attenuate the development of AS plaques. Similarly, control of proliferation of structurally and functionally altered, subclincal abnormal pulmonary endothelial cells could prevent formation of plexiform lesions associated with remodeled pulmonary vasculature found in pulmonary hypertensive specimens $(40,43-45)$ both of which may contribute towards a potentially efficacious preventive strategy for CVD.

Impaired nitric oxide (NO) synthesis has been reported in AS and the primary source of vascular NO is likely to come from endothelial cells $(12,22)$. Therefore, in this study we investigated the effects of resveratrol on eNOS expression. Treatment of HAECs and HPAECs by resveratrol resulted in down-regulation of eNOS gene expression, in contrast to our previous observation showing that resveratrol induced eNOS protein expression in BPAECs (26). While the significance and basis for these discordant observations remain to be investigated in detail, they clearly point to complex, cell type and species-dependent control of eNOS, by exposure to cardioprotective cues, such as resveratrol. In addition to eNOS, endothelin (ET) also plays an important role in pathogenesis of CVD particularly in congestive heart failure. Accordingly, in this study we also investigated the effects of resveratrol on ppET-1 mRNA expression. Our results showed that resveratrol inhibited ppET-1 expression. Moreover, the inhibition of ppET-1 was more pronounced in HAECs than HPAECs, further supporting that the cardioprotective effects of resveratrol may be cell type-dependent.

Since the differentially effective growth response in HAECs and HPAECs elicited by resveratrol may be attributed to functionally related gene changes, studies employing the signal transduction pathway finder cDNA array were performed to test this possibility, as results derived from array analysis are expected to provide a panoramic mechanistic framework relevant to the resveratrol induced signaling changes. Using this approach, distinct and/or overlapping signal transduction pathways involved in control HAECs and HPAECs cell growth and gene expression by resveratrol were identified, validating that resveratrol indeed triggered cell type-dependent gene regulatory effects (Tables I and II). Notably, in HAECs, this grape polyphenol elicited growth response and gene control changes, in part mediated through Hedgehog, p53 and survival pathway, whereas by contrast, resveratrol induced changes in HPAECs possibly through the Hedgehog and retinoic acid pathways.

In conclusion, the results of this communication suggest that resveratrol controls proliferation of human endotheial cells irrespective of their anatomical origin, albeit might exert endothelial cell type-specific affects utilizing distinct and preferential signaling pathways. Overall, though, the data lend credence to the categorization of resveratrol as an example of diet-derived phytochemicals capable of restricting endothelial cell growth and hence exhibits the potential of being developed as an efficacious preventive strategy for CVD.

\section{Acknowledgements}

Studies reported herein were supported in part by the Intramural Sponsored Research Program of New York Medical
College and by Phillip Morris USA Inc. and Phillip Morris International (to J.M.W.).

\section{References}

1. Murray CJ, Kulkarni SC and Ezzati M: Understanding the coronary heart disease versus total cardiovascular mortality paradox: a method to enhance the comparability of cardiovascular death statistics in the United States. Circulation 113: 2071-2081, 2006.

2. Mathers CD and Loncar D: Projections of global mortality and burden of disease from 2002 to 2030. PLoS Med 3: e442, 2006.

3. Murray CJ, Lopez AD, Black R, et al: Global burden of disease 2005: call for collaborators. Lancet 370: 109-110, 2007.

4. Danaei G, Ding EL, Mozaffarian D, et al: The preventable causes of death in the United States: comparative risk assessment of dietary, lifestyle, and metabolic risk factors. PLoS Med 6: e1000058, 2009.

5. Rizzo M, Corrado E, Coppola G, Muratori I, Novo G and Novo S: Prediction of cardio- and cerebro-vascular events in patients with subclinical carotid atherosclerosis and low HDL-cholesterol. Atherosclerosis 200: 389-395, 2008.

6. Mullenix PS, Steele SR, Martin MJ, Starnes BW and Andersen CA: C-reactive protein level and traditional vascular risk factors in the prediction of carotid stenosis. Arch Surg 142: 1066-1071, 2007.

7. Carter SJ, Roberts MB, Salter J and Eaton CB: Relationship between Mediterranean Diet Score and atherothrombotic risk: findings from the Third National Health and Nutrition Examination Survey (NHANES III), 1988-1994. Atherosclerosis 210: 630-636, 2010.

8. Das S, Lekli I, Das M, et al: Cardioprotection with palm oil tocotrienols: comparision of different isomers. Am J Physiol Heart Circ Physiol 294: H970-H978, 2008.

9. Shukla SK, Gupta S, Ojha SK and Sharma SB: Cardiovascular friendly natural products: a promising approach in the management of CVD. Nat Prod Res 24: 873-898, 2010.

10. Bertelli AA and Das DK: Grapes, wines, resveratrol, and heart health. J Cardiovasc Pharmacol 54: 468-476, 2009.

11. Renaud S and de Lorgeril M: Wine, alcohol, platelets, and the French paradox for coronary heart disease. Lancet 339 : 1523-1526, 1992.

12. Wu JM, Wang ZR, Hsieh TC, Bruder JL, Zou JG and Huang YZ: Mechanism of cardioprotection by resveratrol, a phenolic antioxidant present in red wine (Review). Int J Mol Med 8: 3-17, 2001.

13. Collins MA, Neafsey EJ, Mukamal KJ, et al: Alcohol in moderation, cardioprotection, and neuroprotection: epidemiological considerations and mechanistic studies. Alcohol Clin Exp Res 33: 206-219, 2009.

14. Vidavalur R, Otani H, Singal PK and Maulik N: Significance of wine and resveratrol in cardiovascular disease: French paradox revisited. Exp Clin Cardiol 11: 217-225, 2006.

15. Zou J, Huang Y, Chen Q, Wei E, Cao K and Wu JM: Effects of resveratrol on oxidative modification of human low density lipoprotein. Chin Med J 113: 99-102, 2000.

16. Belguendouz L, Fremont L and Linard A: Resveratrol inhibits metal ion-dependent and independent peroxidation of porcine low-density lipoproteins. Biochem Pharmacol 53: 1347-1355, 1997.

17. Zou J, Huang Y, Chen Q, et al: Suppression of mitogenesis and regulation of cell cycle traverse by resveratrol in cultured smooth muscle cells. Int J Oncol 15: 647-651, 1999.

18. Poussier B, Cordova AC, Becquemin JP and Sumpio BE: Resveratrol inhibits vascular smooth muscle cell proliferation and induces apoptosis. J Vasc Surg 42: 1190-1197, 2005.

19. Brito PM, Devillard R, Negre-Salvayre A, et al: Resveratrol inhibits the mTOR mitogenic signaling evoked by oxidized LDL in smooth muscle cells. Atherosclerosis 205: 126-134, 2009.

20. Wang Z, Zou J, Huang Y, Cao K, Xu Y and Wu JM: Effect of resveratrol on platelet aggregation in vivo and in vitro. Chin Med J 115: 378-380, 2002.

21. Kirk RI, Deitch JA, Wu JM and Lerea KM: Resveratrol decreases early signaling events in washed platelets but has little effect on platalet in whole food. Blood Cells Mol Dis 26: 144-150, 2000.

22. Lin KH, Hsiao G, Shih CM, Chou DS and Sheu JR: Mechanisms of resveratrol-induced platelet apoptosis. Cardiovasc Res 83: 575-585, 2009. 
23. Zou J, Huang Y, Cao K, et al: Effect of resveratrol on intimal hyperplasia after endothelial denudation in an experimental rabbit model. Life Sci 68: 153-163, 2000.

24. Choi KH, Kim JE, Song NR, et al: Phosphoinositide 3-kinase is a novel target of piceatannol for inhibiting PDGF-BB-induced proliferation and migration in human aortic smooth muscle cells. Cardiovasc Res 85: 836-844, 2010.

25. Hsieh TC, Juan G, Darzynkiewicz Z and Wu JM: Resveratrol increases nitric oxide synthase, induces accumulation of p53 and p21(WAF1/CIP1), and suppresses cultured bovine pulmonary artery endothelial cell proliferation by perturbing progression through S and G2. Cancer Res 59: 2596-2601, 1999.

26. Bruder JL, Hsieh T, Lerea KM, Olson SC and Wu JM: Induced cytoskeletal changes in bovine pulmonary artery endothelial cells by resveratrol and the accompanying modified responses to arterial shear stress. BMC Cell Biol 2: 1, 2001.

27. Klinge CM, Wickramasinghe NS, Ivanova MM and Dougherty SM: Resveratrol stimulates nitric oxide production by increasing estrogen receptor alpha-Src-caveolin-1 interaction and phosphorylation in human umbilical vein endothelial cells. FASEB J 22: 2185-2197, 2008.

28. Aird WC: Endothelium as an organ system. Crit Care Med 32 S271-S279, 2004.

29. Aird WC: Mechanisms of endothelial cell heterogeneity in health and disease. Circ Res 98: 159-162, 2006.

30. Aird WC: Endothelial cell heterogeneity and atherosclerosis. Curr Atheroscler Rep 8: 69-75, 2006.

31. Aird WC: Endothelial cell heterogeneity. Crit Care Med 31: S221-S230, 2003.

32. DiPietrantonio AM, Hsieh TC and Wu JM: Specific processing of poly(ADP-ribose) polymerase, accompanied by activation of caspase-3 and elevation/reduction of ceramide/hydrogen peroxide levels, during induction of apoptosis in host HL-60 cells infected by the human granulocytic ehrlichiosis (HGE) agent. IUBMB Life 49: 49-55, 2000.

33. Hsieh TC, Kunicki J, Darzynkiewicz Z and Wu JM: Effects of extracts of Coriolus versicolor (I'm-Yunity) on cell-cycle progression and expression of interleukins- 1 beta, -6 , and -8 in promyelocytic HL-60 leukemic cells and mitogenically stimulated and nonstimulated human lymphocytes. J Altern Complement Med 8: 591-602, 2002.

34. Hsieh TC, Wu P, Park S and Wu JM: Induction of cell cycle changes and modulation of apoptogenic/anti-apoptotic and extracellular signaling regulatory protein expression by water extracts of I'm-Yunity (PSP). BMC Complement Altern Med 6: $30,2006$.
35. DiPietrantonio AM, Hsieh TC, Olson SC and Wu JM: Regulation of G1/S transition and induction of apoptosis in HL-60 leukemia cells by fenretinide (4HPR). Int J Cancer 78: 53-61, 1998.

36. Darzynkiewicz Z, Bedner E and Smolewski P: Flow cytometry in analysis of cell cycle and apoptosis. Semin Hematol 38: 179-193, 2001.

37. Hsieh TC, Lu X, Wang Z and Wu JM: Induction of quinone reductase NQO1 by resveratrol in human K562 cells involves the antioxidant response element ARE and is accompanied by nuclear translocation of transcription factor Nrf2. Med Chem 2: 275-285, 2006.

38. Lu X, Guo J and Hsieh TC: PC-SPES inhibits cell proliferation by modulating $\mathrm{p} 21$, cyclins $\mathrm{D}, \mathrm{E}$ and $\mathrm{B}$ and multiple cell cyclerelated genes in prostate cancer cells. Cell Cycle 2: 59-63, 2003.

39. Hsieh TC, Lu X, Guo J, et al: Effects of herbal preparation Equiguard on hormone-responsive and hormone-refractory prostate carcinoma cells: mechanistic studies. Int J Oncol 20: 681-689, 2002.

40. Wang Z, Chen Y, Labinskyy N, Hsieh TC, Ungvari Z and Wu JM: Regulation of proliferation and gene expression in cultured human aortic smooth muscle cells by resveratrol and standardized grape extracts. Biochem Biophys Res Commun 346: 367-376, 2006.

41. Haider UG, Sorescu D, Griendling KK, Vollmar AM and Dirsch VM: Resveratrol increases serine15-phosphorylated but transcriptionally impaired p53 and induces a reversible DNA replication block in serum-activated vascular smooth muscle cells. Mol Pharmacol 63: 925-932, 2003.

42. Haider UG, Sorescu D, Griendling KK, Vollmar AM and Dirsch VM: Resveratrol suppresses angiotensin II-induced Akt/protein kinase B and p70 S6 kinase phosphorylation and subsequent hypertrophy in rat aortic smooth muscle cells. Mol Pharmacol 62: 772-777, 2002.

43. Naito Y, Tsujino T, Matsumoto M, Sakoda T, Ohyanagi M and Masuyama T: Adaptive response of the heart to long-term anemia induced by iron deficiency. Am J Physiol Heart Circ Physiol 296: H585-H593, 2009.

44. Walker JL, Loscalzo J and Zhang YY: 5-Lipoxygenase and human pulmonary artery endothelial cell proliferation. Am J Physiol Heart Circ Physiol 282: H585-H593, 2002.

45. Iwase M, Uechi M, Vatner DE, et al: Cardiomyopathy induced by cardiac Gs alpha overexpression. Am J Physiol 272: H585H589, 1997. 